\title{
Forskeren som dramaturg - dramaturgi som refleksiv metodologi
}

\author{
Kristian Nødtvedt Knudsen ${ }^{\star}$ \\ NTNU Norges teknisk-naturvitenskapelige universitet
}

\begin{abstract}
Sammendrag
Artiklens hensigt er at undersøge, hvordan dramaturgi som et teoretisk koncept (Pavis, 2014; Szatkowski, 2017) kan fungere som en metodologisk platform i relation til kunstbaseret forskning. I kunstbaseret forskning får forskeren mulighed for at antage en eksplorerende tilgang til forskningspraksissen samt anvende en bred vifte af forskningstilgange- og tematikker. Den kunstbaserede forsknings strategier kan gøre det udfordrende for kunstner-forskeren at navigere $i$ et metodologisk krydsfelt, som i takt med flere og flere divergerende tolkninger bliver mere og mere komplekst. I denne artikel undersøges og præsenteres et forslag om dramaturgi som refleksiv metodologi. Jeg foreslår, at dramaturgi som refleksiv metodologi tilfører kunstner-forskeren et bredt tolkningsrepertoire, hvor dramaturgiske komponenter som divergens, fragmentering, transformering og flerstemmighed er styrende for den refleksive forskningsproces.
\end{abstract}

\section{Nøkkelord: Kunstbaseret forskning; dramaturgi; refleksiv metodologi; performative research}

\begin{abstract}
The purpose of this article is to investigate how dramaturgy as a theoretical concept (Pavis, 2014; Szatkowski, 2017) can act as a methodological platform in relation to arts-based research. In artsbased research, the researcher has the opportunity to adopt an exploratory approach to research practices, as well as applying a wide range of research approaches and themes. The arts-based research strategies can make it challenging for the artist-researcher to navigate in a methodological field, which, in line with increasingly divergent interpretations, becomes progressively complex. This article examines and presents a proposal on dramaturgy as a reflexive methodology. The author suggests that dramaturgy as a reflexive methodology provides the artist-researcher with a broad interpretation repertoire, where dramaturgical components such as divergence, fragmentation, transformation and polyphony are the guiding principles for the reflexive research process.
\end{abstract}

Keywords: Arts-based research; dramaturgy; reflexive methodology; performative research Received: October, 2017; Accepted: February 2018; Published: March, 2018.

\footnotetext{
^Korrespondanse: Kristian Nødtvedt Knudsen, Institutt for lærerutdanning, NTNU 7491 Trondheim. Epost: kristian.knudsen@ntnu.no
} 


\section{K. N. Knudsen}

All the world is a dramaturgical stage. (Pavis, 2014)

Det følgende tager sit afsæt i erfaringer jeg har gjort mig gennem mit ph.d.-projekt "\#iLive - konturer af en performativ dramadidaktik i en digital samtid" (Knudsen, 2017b). I denne artikel retter jeg fokus mod de metodologiske overvejelser, jeg har haft i løbet af ph.d.-projektets varighed. Med metodologi mener jeg alle de valg, som kunstner-forskeren står overfor i løbet af forskningsprocessen og måden kunstner-forskeren både forholder sig kritisk til egen praksis og er kunstnerisk skabende i samme proces (Østern \& Letnes, 2017). Ph.d.-projektets overordnede studie er forankret $\mathrm{i}$ et performativt, kunstbaseret forskningsparadigme samt en abduktiv forskningslogik. I denne type forskningsstrategi får forskeren mulighed for at antage en eksplorerende tilgang til forskningspraksissen samt anvende flere forskellige forskningstilgange- og tematikker (Gjærum \& Rasmussen, 2012; Kershaw, 2006; Nicholson \& Kershaw, 2011; Rasmussen, 2013; Smith \& Dean, 2009; Østern \& Letnes, 2017). Risikoen er dog, at den metodiske variation og forskningsprocessens kontinuerlige transformation kan skabe mere forvirring end oplysning i forskningsprocessen.

Udgangspunktet for denne studie skal findes i teori om, at det dramaturgiske kan udgøre en fælles platform - et kommunikativt mødested - mellem epistemologi, ontologi og metode (Pavis, 2014; Szatkowski, 2017). Hensigten med denne artikel er at undersøge, hvordan dramaturgi som teoretisk koncept kan anvendes som metodologisk platform $i$ relation til kunstbaseret forskning. Det vil sige, det er en udforskning af det metodologiske arbejde, som sættes i forgrunden i denne artikel, og selve arbejdet med ph.d.-projektet integreres som refleksive sideblik i løbet af studien. I artiklen præsenteres indledningsvis kunstbaseret forskning og dramaturgibegrebet. Gennem refleksive sideblik til \#iLive og teori om refleksiv forskning (Alvesson \& Sköldberg, 2008) drøftes, hvad det dramaturgiske kan bidrage med som refleksiv metodologi i forbindelse med kunstbaseret forskning.

\section{Kunsten at forske performativt med kunsten}

Kunstbaseret forskning indeholder et bredt spekter af forskellige retninger såsom art(s) based research, art as research, performative research, practice-led research og research-led practice for at nævne nogle få. Kunstbaseret forskning markerer en fornyet interesse for kunstens epistemologiske dimension. Denne fornyede interesse har de sidste 20 år ført til en bred vifte af forskningsplatforme, hvor kunsterfaringer og refleksion i og om en form for kunstpraksis behandles (Rasmussen, 2013; Østern \& Letnes, 2017). Der er altså tale om et forholdsvis ungt forskningsområde, hvori flere forskellige terminologier og både kunstneriske, filosofiske og videnskabelige forankringer florerer. Kunstbaseret forskning bærer på et ønske om at ville bevæge sig bort fra dikotomien mellem kunst og videnskab og i stedet skabe en praksis, hvor refleksioner knyttet til form og indhold er en kontinuerlig del af forskningsprocessen. Deraf også betegnelserne praksis-ledet forskning og praksisbaseret forskning. 
I 2006 præsenterer Brad Haseman A Manifesto for Performative Research, hvor han redegør for et performativt forskningsparadigme. Hasemans manifest skal ses i sammenhæng med 1990'ernes performative vending samt en omfattende debat særligt i England og Australien omhandlende forskningsstrategier i relation til performative og kreative fagfelter (Ulvund, 2012, s. 56). En performativ tilgang til forskning kan ses som en kategori inden for praksisledet og kunstbaseret forskning. Kendetegnende for forskningen er, at den forudsætter at være praksiscentreret og åbner op for, at forskeren kan "give sig hen til" forskningen og bevæge sig i krydsfelterne mellem ncerhed/distance, teori/praksis og kunst/videnskab. Ligeledes imødekommes og inkluderes andre sprogformer eller symboler som tegn på mening. Det empiriske materiale kan blandt andet bestå af:

[...] forms of symbolic data other than words in discursive text. These include material forms of practice, of still and moving images, of music and sound, of live action and digital code" (Haseman, 2006, s. 103).

Forskningens performative dimension kommer til udtryk i måden, det empiriske materiale på samme tid både opererer som et udtryk for forskning og som forskning $i$ sig selv (Haseman, 2006). Den kunstbaserede forsker får således mulighed for at varetage den flygtige og dynamiske dimension ved forskningspraksissen (Jf. Fels, 2015; Ulvund, 2012). Udviklingen af forskning i en kunstfaglig kontekst kan ses som en variant, hvor kunsten konkretiseres som et metodologisk univers (Gjærum \& Rasmussen, 2012). Ulempen er dog, at forskningspraksissen risikerer at blive mere kompleks end andre ikke-praksisledede forskningsprocesser, da det empiriske materiale ikke nødvendigvis kan fanges gennem etablerede kvalitative eller kvantitative metoder. Ej heller gennem det positivistiske ideal om en distanceret og observerende forsker, som anskuer objektet på afstand. Tværtimod er både den kunstbaserede og kvalitative forsker styret af sine værdier og forforståelse, som bringes med ind i den kunstneriske praksis og bliver en del af forskningsprojektet (Gergen \& Gergen, 2018). Når forskeren "giver sig hen" til forskningen, opstår der samtidig en risiko for, at den kunstneriske praksis og processerne bliver interne. Det vil sige, de kunstneriske processer får ikke betydning ud over kunstnerens egen horisont. For at imødegå dette, skal den kunstbaserede forsker kunne diskutere kvaliteten af metoder ud fra en større videnskabsteoretisk oversigt og tydeliggjorte erfaringer. Det er ligeledes væsentligt, at valg af form og indhold bliver formidlet på en refleksiv og transparent måde, og det forudsætter metodologiske greb.

Det ville være oplagt at indvende, at et dramaturgisk perspektiv, som jeg forsøger at skrive frem i denne artikel, vil være at kaste endnu mere vand på nogens mølle. Som beskrevet, florerer der allerede et utal af teorier og kunstneriske, filosofiske og videnskabelige forankringer i relation til kunstbaseret forskning. Grunden til, at jeg alligevel vælger at kaste mig ud i dette forsøg, skyldes erfaringer, jeg gjorde mig i forbindelse med mit eget ph.d.-projekt. I det følgende afsnit foretager jeg studiens første refleksive sideblik og giver en kort redegørelse af ph.d.-projektet som et eksempel på kunstbaseret forskning og de udfordringer, som opstod undervejs. 


\section{K. N. Knudsen}

\section{\#iLive - at navigere i en kunstfagdidaktisk forskningspraksis}

Afhandlingen er artikelbaseret og består af fire artikler og en samlende kappe. Artiklerne repræsenterer delstudier, som hver især indeholder forskellige metoder og forskningsstrategier. Jeg anvendte blandt andet performative inquiry (Fels, 2015) som en måde at sætte mig selv på spil på som kunstner-forsker i mødet mellem den kunstneriske praksis, jeg er en del af (drama/teater), og det fænomen jeg forskede på (de sociale medier). Af andre metoder og forskningstilgange kan nævnes selvstudie (Knudsen, 2015), udviklingsforskning (Knudsen, 2015) samt spørgeskema og deltagerlog (Knudsen, 2017a; 2018). Afhandlingens titel, \#iLive, er hentet fra et dramadidaktisk undervisningsdesign, som jeg udviklede på baggrund af de erfaringer, jeg gjorde mig gennem de performative undersøgelser. \#iLive blev gennemført med cirka 90 gymnasieelever.

Den store variation mellem teoretiske, metodiske og epistemologiske aspekter i forskningsprocessen ræsonnerer med en abduktiv forskningslogik og kunstbaseret forskning (Jf. Gjærum \& Rasmussen, 2012). En abduktiv forskningslogik kendetegnes ved, at en kontinuerlig pendling mellem praksis, forskning og teori bidrager til at udvikle nye forskningsspørgsmål (Peirce, 1998). Forskningsforløbet i abduktiv forskningslogik bliver således dynamisk og fragmenteret. Den valgte forskningslogik har bidraget til, at ph.d.-projektet har gennemgået en transformation i løbet af projektets fireårige periode. I begyndelsen af mit ph.d.-projekt, da både det teoretiske grundlag og arbejdshypoteserne var på et skitseplan, var det primære forskningsfokus rettet mod at undersøge meningsskabende processer knyttet til kropslig refleksion i en dramadidaktisk kontekst. Men i løbet af projektets fireårige periode og i takt med pendlingen mellem forskning, praksis og teori skete der et teoretisk skifte fra kropslig refleksion og æstetisk pragmatisme til et mere performativt og senmoderne perspektiv på subjekt og erkendelse. Én af grundene til dette skifte skyldes fænomenet, som jeg bragte med ind i den kunstneriske praksis. De sociale mediers komplekse kommunikative systemer udfordrede dramadidaktikkens og dramapædagogikkens måde at skabe meningsskabende processer på. I dramadidaktisk arbejde iscenesættes meningsskabende processer $i$ en tydelig skelnen mellem fiktion og virkelighed (Heggstad, 2012; Sæbø, 2016). Dramadidaktikkens fiktionsarbejde kom i konflikt med de sociale mediers kommunikative og meningsskabende principper, da distinktionen mellem fiktion og virkelighed opløses ${ }^{1}$. I praksis medførte dette, at jeg midtvejs i ph.d.-projektets periode oplevede, at den kunstneriske kontekst, som jeg var en del af, blev fremmed (for mig selv), når jeg forsøgte at forholde mig kritisk til den. Den kundskab som blev skabt, når jeg "gav mig hen" til forskningen, kunne ikke længere adapteres til min position inden for et æstetisk pragmatisk kundskabssyn (Dewey, 1934/1980; Shusterman, 1992/2000). Forskningsprocessens udvikling kan ses som et tegn på de konstante svingninger mellem praksis og teori, som $i$ abduktionens logik genererer ny praksis og ny teori. Men som eksemplet også viser, så opstod der brydninger eller blokeringer, når

${ }^{1}$ For en grundigere redegørelse henvises til afhandlingen (Knudsen, 2017, s. 53). 
jeg som forsker bevægede mig mellem (1) forskningens transformative dimension, (2) projektets forskningsdesign og metodik, (3) epistemologiske og ontologiske ståsteder og (4) fænomenerne, som jeg forskede på (de sociale mediers potentiale for dramadidaktisk fornyelse). Brydningerne medførte, at den kundskab og de kommunikative budskaber, som blev skabt gennem de kunstbaserede forskningsstrategier, ikke længere gav mening for mig selv som forsker og dramapædagog. Jeg blev derfor nødt til at re-positionere mig som kunstner-forsker og udvikle en metodologisk platform, hvor både divergerende teorier og kundskabssyn kunne isoleres og undersøges som enkeltstående hændelser. Og på samme tid også være sammenflettede på et mere overordnet metodologisk niveau. I det følgende afsnit vil jeg skifte fokus til teori om dramaturgi og undersøge, hvordan det dramaturgiske kan udgøre en fælles platform - et kommunikativt mødested - mellem epistemologi, ontologi og metode.

\section{Verden er en (dramaturgisk) scene}

feg spejler mig $i$ min selfiestang og ser et hav af FORTELLINGER, ROLLER og AKTØRER. Hvem er du på de sociale medier, og hvordan lever du med de sociale medier? 13 timers videomateriale, hvad har jeg fanget? Er der noget, som kan bruges til noget? Ser på en skcerm $i 13$ timer. Herregud! feg må have et overblik, men hvad skal jeg se efter? STRUKTUR og FRAGMENTER - 15 leringshcendelser med forskellige opgaver. Et ANSLAG - en \#iLive boks, en QRkode, en videohilsen. Hvad gør det ved deltagernes møde med laringsprocessen? TID - $i$ videoen fär de en opgave af varten; "Ta en selfie og post den på Instagram med \#iLive, velkommen til \#iLive!” - Deltagerne dokumenterer deres deltagelse $i$ \#iLive, de er til stede analogt $i$ RUMMET, men også digitalt på de sociale mediers udvidede scenerum. Hvad gør det ved TIDEN? Hvad gør det med FIKTIONENs funktion $i$ cestetiske laringsprocesser?

Ovenstående fortælling er en narrativ beskrivelse baseret på undertegnedes arbejde med det empiriske materiale og min anvendelse af dramaturgi som et analytisk værktøj. Dramaturgibegrebet relateres ofte til teaterets verden og måden, instruktøren eller dramaturgen arbejder med en forestilling på (Gladsø, Gjervan, Hovik \& Skagen, 2015). At tænke som en dramaturg handler om at være bevidst om dramatikkens narrative strukturer, rytme, tempo, rum, tid, fiktion og anslag, for at nævne nogle få. Dramaturgisk tænkning indeholder en analytisk dimension, som operationaliseres både i en tekst- og en forestillingsanalytisk kontekst (Gladsø et al., 2015; Kjølner og Szatkowski, 1991; Szatkowski 1989). Den stærke kobling mellem dramaturgi og teater medfører, at den udvikling, teatret som kunstform gennemgår, særligt fra 1960'erne og frem, også får indflydelse på dramaturgibegrebets udvikling. Ifølge Patrice Pavis (2014) resulterer påkaldelsen af forfatterens død (Jf. Barthes, 1977) i, at den traditionelle dramaturg lider samme skæbne. Den klassiske græske dramaturgis fokus på tekstens budskab, komposition og formidling af disse tilsidesættes i for eksempel det prostdramatiske teater og andre mere eksperimenterende teatergenrer. I disse "nye" teatergenrer insisterer tilskueren ikke længere på at skulle forstå alt, hvad der foregår på scenen, og det åbner op for andre måder at tænke dramaturgi på (Pavis, 2014, s. 22). Pavis beskriver dramaturgiens udvikling som både en triumf og 


\section{K. N. Knudsen}

en eksplosion. På den ene side vidner begrebets indtog i flere forskellige kontekster om dets potentiale og anvendelighed. På den anden side risikerer det samme omfang af brugsområder at reducere begrebets potentiale.

We might be at a turning point of theoretical, cultural and social life, and even, more prosaically, of theoretical thinking. The question is thus: should we give up theory as something unattainable and useless, as postmodernist and postdramatic ideology encourages us to do? Or should we, as I suggest, resume our theoretical labours, not necessarily by enumerating all the tasks of the dramaturge, but by looking for adequate methodological and theoretical tools, in order to think the new situation we are in (Pavis, 2014, s. 26).

Pavis er af den opfattelse, at teoretisk fornyelse har grobund i praksis, men understreger ligeledes, at det er nødvendigt, at dramaturgen er bevidst om, hvilke metoder som egner sig bedst til at undersøge nye praksisfelter (Pavis, 2014, s. 26). Spørgsmålet er, hvad er det for dramaturgiske komponenter, som bliver sat i spil med de metodologiske og teoretiske værktøjer, som Pavis beskriver? Og kan kunstbaserede forskningsprocesser være en type praksis, hvor sådanne metodologiske og teoretiske redskaber udvikles? I det følgende illustreres et udvalg af forskellige perspektiver og kontekster, hvor dramaturgibegrebet anvendes.

\section{Dramaturgi i didaktisk kontekst}

Anna-Lena Østern (2014) undersøger, hvordan dramaturgisk tænkning kan overføres til didaktisk virksomhed. Hendes mål er at bidrage til en fornyelse af undervisningsplanlægning og klasserumsledelse (Østern, 2014, s. 63). At tænke som en dramaturg i undervisningen handler om at overveje, hvilken historie man som lærer $ø$ nsker at fortælle. Svaret på spørgsmålet former undervisningsforløbet og har indflydelse på lærerens måde at iscenesætte et tema for eleverne på. Østern folder dramaturgibegrebet ud som et didaktisk værktøj, hvor de dramaturgiske modeller åbner op for eller inviterer til forskellige måder at arbejde med læring på.

\section{Dramaturgi som epistemologi}

Tor-Helge Allern (2003) undersøger kundskabsprocessen i drama og dramapædagogik med udgangspunkt i forholdet mellem epistemologi og dramaturgi. Allern er optaget af, hvordan forskellige dramaturgier kan knyttes til forskellige kundskabsteoretiske positioner. Dramaturgibegrebet løftes op på et epistemologisk niveau og bliver et redskab til at anskue, hvordan mening skabes i mødet mellem deltageren og en kunstpraksis.

\section{Dramaturgisk tænkning i kunstbaseret forskning}

I relation til kunstbaseret forskning anvendes dramaturgisk analyse inden for de former for anvendt teaterforskning, som bevæger sig udover den litterære tekst og ser på drama/teaterpraksis som udvidet tekst (Rasmussen, 2012). I disse tilfælde tilføres drama/teaterpraksissen et deltagerorienteret kundskabssyn, hvor mening produceres og analyseres ud fra erfaringer og hændelser. Disse erfaringer og hændelser lader sig 
ikke altid udtrykke i diskursive former, men kan konstrueres ved hjælp af metaforer fra teatrets verden. Det der adskiller denne type forskning fra kvalitativ forskning og akademisk skrivning, er, at teaterlaboratoriet ligestilles med den skriftlige analyse som udviklings- og refleksionsarena (Rasmussen, 2013).

De tre eksempler tegner et billede af, hvordan dramaturgisk tænkning anvendes i forskellige forsknings- og undervisningsrelaterede kontekster. Eksemplerne har det til fælles, at konteksten, som dramaturgien bringes med ind i, transformeres til eller anskues som et teaterlaboratorie. Dramaturgiske begreber som anslag, rytme, fiktionslag og narrativer er eksempler på analytiske eller teoretiske komponenter, som bringes med ind i forskningspraksissen. De dramaturgiske komponenter tilfører forskeren værktøj eller tilgange, som kan adapteres til forskerens måde at udvikle og analysere empirisk materiale på. I artiklens første refleksive sideblik beskrev jeg, hvordan der opstod brydninger i krydsfeltet mellem ph.d.-projektets metodologiske platform og de valg, jeg foretog mig i relation til epistemologiske, ontologiske og metodiske ståsteder. Spørgsmålet er således, om dramaturgi som et teoretisk koncept kan udvides til også at favne forskningens metodologiske processer og ikke kun den kontekst, som dramaturgien bringes med ind i? Det ville i så fald medføre, at hele den kunstbaserede forskningsproces anskues som et teaterlaboratorie, inden for hvilket forskeren kontinuerligt skifter mellem at være kunstner, forsker, underviser og dramaturg.

\section{Dramaturgisk tænkning i en metodologisk kontekst}

I sin drøftelse af dramaturgibegrebet argumenterer Janek Szatkowski for dramaturgi som en måde at reducere kommunikativ kompleksitet på (Szatkowski, 2011, 2017). Særligt i relation til den kommunikation som gennemsyrer samfundets sociale strukturer. Szatkowski ønsker at etablere dramaturgi som et teoretisk koncept, der åbner op for at observere refleksive processer i forskellige kunstneriske kontekster. Han påpeger, i tråd med Pavis, at det forudsætter en forståelse af og et kendskab til, hvordan kunstneriske processer fungerer i praksis. Szatkowski tilfører en kommunikativ dimension til måden at tænke dramaturgi på. Dramaturgibegrebet har fra dets begyndelse været operationaliseret i sociale og relationelle kontekster såsom uddannelse, religion og politik (Szatkowski, 2017). Szatkowski henviser til måden, religiøse og statslige ledere op igennem tiden har manipuleret med narrativt indhold og kommunikationsstrategier på. Deres hensigt var at forme og formidle deres budskaber til samfundets subjekter. I dette perspektiv bliver det dramaturgiske først og fremmest en kommunikativ egenskab, som subjektet anvender for at analysere og kritisk reflektere over kommunikative budskaber og sin egen plads i verden.

Dramaturgy may bring with it important knowledge on interactivity and analytical tools regarding communication and the representation of the digital self on commercial platforms such as Facebook or in non-commercial groups of interest. (Szatkowski, 2017, s. 12). 


\section{K. N. Knudsen}

Szatkowski foreslår dramaturgi som et wide-range teoretisk koncept. Definitionen wide-range skal ses som en modsætning til modernismens tanke om en grand theory (Szatkowski, 2017, s. 18). Forskning i et dramaturgisk perspektiv handler ikke om at ville afdække en sandhed bag en lineær virkelighed, som fremstilles. Et lignende syn på forskning skitseres af Kenneth J. Gergen og Mary Gergen i deres beskrivelse af performativ forskning: "[...] such research does not simply try to reflect the world as it is, but serves as an action that might change that world" (Gergen \& Gergen 2017, s. 54). Både Szatkowski og Gergen og Gergen fokuserer på den form for viden, som opstår i handlinger mellem mennesker $i$ samfundet og deres kommunikation om samfundet (Szatkowksi, 2017; Gergen \& Gergen, 2017). Fra at have været et begreb som først og fremmest tilhører teatrets verden, udvides det dramaturgiske til at blive et kommunikativt mødested, som åbner op for at undersøge kropslig kommunikation mellem mennesker i samfundet og deres måde at kommunikere om samfundet på.

We need to develop a theory that is applicable in both micro- and macro-analytical processes, and it must allow us to apply dimensions of meaning-making procedures (Szatkowski, 2017, s. 20).

Mikro- og makroniveauernes dramaturgiske funktion ligger i, at de kan hjælpe forskeren med at systematisere mængden af kommunikative budskaber, som florere i forskningsprocessen og derigennem reducere niveauet af kompleksitet. De to niveauer transformeres til dramaturgiske komponenter, som kan adapteres til forskningens overordnede design.

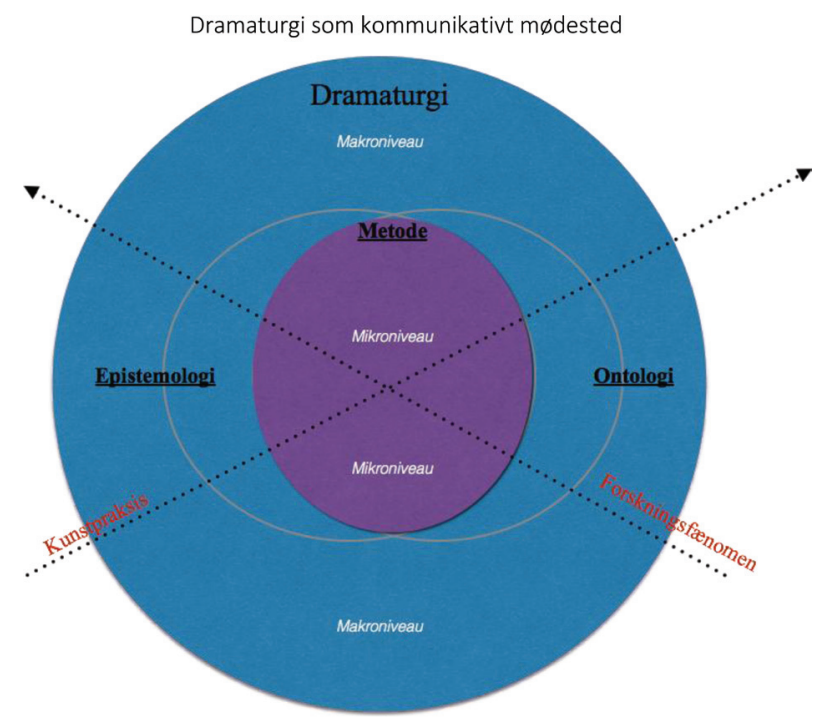

Figur 1. I figuren bliver dramaturgi (markeret med blå farve) en platform, hvorpå mikro- og makroniveauets kommunikative budskaber kan mødes. I en kunstbaseret forskningskontekst er disse niveauer i konstant berøring med hinanden og transformeres kontinuerligt i løbet af den kunstbaserede forskningsproces. 
I figur 1 har jeg forsøgt at skitsere, hvordan det dramaturgiske $\mathrm{i}$ en kunstbaseret forskningskontekst bliver et kommunikativt mødested mellem epistemologi, ontologi og metode. Eftersom det dramaturgiske placeres i et wide-range teoretisk koncept, så åbnes der op for, at forskeren kan bringe divergerende teorier med ind i forskningsdesignet. Selvom der navigeres mellem et mikro- og et makroniveau, så er de to niveauer forbundet med hinanden. De komplementerer hinanden, da de gennem hvert sit respektive domæne tegner et billede af de forskellige aspekter, som sammenflettes i forskningsprocessen. På mikroniveauet kan forskeren isolere og undersøge de processer, som opstår i mødet mellem deltager og kunstpraksis, og måden de kommunikerer på (forskningsmetode og generering af empiri). På makroniveauet analyserer forskeren det empiriske materiale og reflekterer over dette gennem epistemologiske og ontologiske perspektiver.

Szatkowskis (2017) kommunikative perspektiv tilfører dramaturgibegrebet en dimension, som ikke forekommer i begrebets andre anvendelsesområder (s. 7-8) og muligvis heller ikke i arbejdet med kunstbaseret forskning generelt. Forskerens dramaturgiske kompetence handler ikke kun om evnen til at analysere et stykke dramatik eller en kunstpraksis og dets komposition (Dramaturgisk tænkning i kunstbaseret forskning). Ej heller at være et redskab i forbindelse med underviserens didaktiske overvejelser eller forskerens epistemologiske overvejelser (Dramaturgi i didaktisk kontekst og Dramaturgi som epistemologi). Det dramaturgiske stiller skarpt på forskningens kommunikative indehold. Både med tanke på den kommunikation, som kommer til udtryk i det empiriske materiale, og i kommunikationen mellem kundskabssyn, metode og epistemologi. I det følgende afsnit foretager jeg endnu et refleksivt sideblik til mit eget ph.d.-projekt og undersøger, hvilke dramaturgiske komponenter dramaturgi som wide-range teori kan tilføre kunstner-forskerens arbejde med metodologi.

\section{Forskningsprocessens dramaturgi}

I ph.d.-projektets tredje delstudie foretager jeg en dramaturgisk analyse af undervisningsforløbet \#iLive. Med udgangspunkt i dramaturgiske modeller (Østern, 2014, s. 60) analyseres \#iLive som et didaktisk design, og jeg undersøger, hvordan performative læringsrum opstår i krydsfeltet mellem dramadidaktik og sociale medier (Knudsen, 2017a). I delstudien opererer jeg med en forståelse af dramaturgi, som svarer til Østerns dramaturgiske tænkning i en didaktisk kontekst. Dramaturgi som kommunikativt mødested opererer her på mikroniveauet, da den dramaturgiske analyse har en metodisk funktion, som applikeres til dele af forskningsprocessens empiriske materiale. En lignende måde at anvende det dramaturgiske på forekommer også i fjerde delstudie, men her skifter fokus til deltagernes perspektiv, og hvordan de udtrykker og former mening i krydsfeltet mellem dramadidaktik og sociale medier (Knudsen, 2018). Som forsker er jeg interesseret i at undersøge kropslig kommunikation mellem mennesker i samfundet og deres måde at kommunikere om samfundet på 


\section{K. N. Knudsen}

(Jf. Szatkowski, 2017). Samtidig åbner tanken om teaterlaboratoriet som en ligestilling med den skriftlige analyse op for at antage en performativ tilgang til forskningsarbejdet. I projektet benyttede jeg blandt andet performative inquiry (Fels, 2015) som en måde at bringe de sociale medier med ind i den kunstneriske praksis på. Mikroniveauets dramaturgiske komponenter gør mig i stand til som forsker at isolere disse hændelser og analysere den meningsskabende proces i krydsfeltet mellem den kunstneriske praksis og forskningsfænomenet. Analyse- og refleksionsarbejdet åbner efterfølgende op for at undersøge det empiriske materiale på et makroniveau. I forbindelse med ph.d.-projektet blev det empiriske materiale og de meningsskabende processer bragt med ind i diskussioner knyttet til æstetisk pragmatisme (Dewey, 1934/1980; Shusterman, 1992/2000), Jacques Rancieres æstetetiske regime og dissensbegreb (2004; 2009) og Anthony Giddens teorier om senmodernitet, subjekt og erkendelse (1991/2013). I Figur 2 illustreres de forskellige kundskabssyn, brug af metoder og ontologiske ståsteder, som opstod i løbet af ph.d.-projektets fireårige periode.

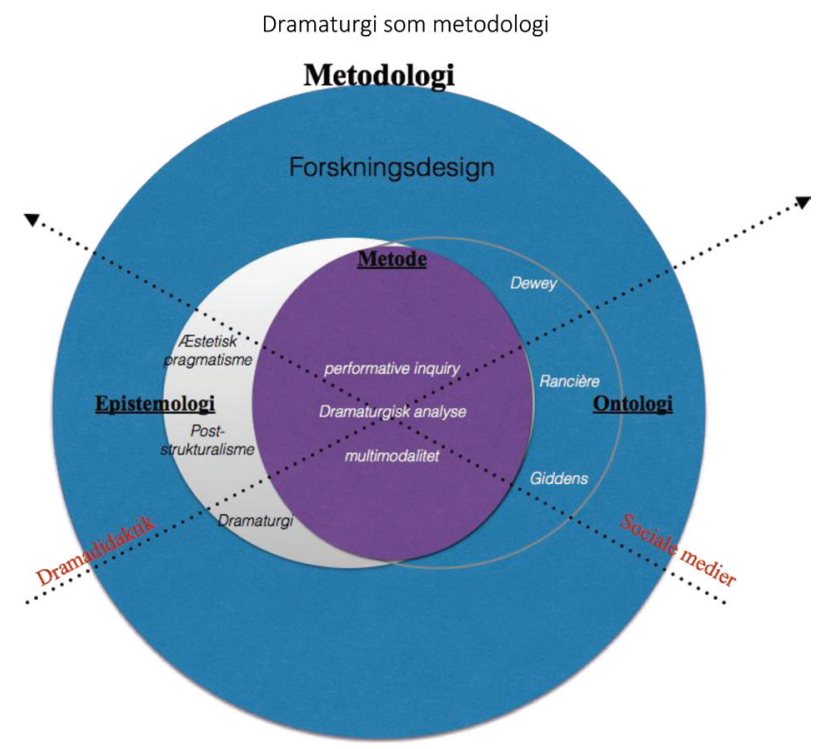

Figur 2. Figuren giver et indblik i ph.d.-projektets metodologiske design. Flere af disse aspekter er vanskelige at forene inden for et forskningsprojekt, da de tilhører forskellige epistemologiske og ontologiske syn. Karakteriseringen af det dramaturgiske som et wide-range teoretisk koncept åbner op for at håndtere divergensen og undersøge de forskellige teorier på et makroniveau.

Med inspiration i Szatkowskis wide-range dramaturgi åbnes der op for at udvikle et metodologisk design, hvor kunstner-forskeren kan operere på et mikro- og et makroniveau. På mikroniveauet får det dramaturgiske en metodisk funktion, da den tilfører forskeren nogle redskaber, hvormed forskningens empiriske materiale kan udvikles, bearbejdes og analyseres. På dette niveau kan forskellige hændelser fryses fast eller være stoppunkter som i for eksempel Performativ inquiry (Fels, 2015) og 
efterfølgende analyseres og granskes yderligere. På figur 2 optræder disse i metodecirklen (performative inquiry, multimodalitet, dramaturgisk analyse). På makroniveauet bringes dramaturgiens kommunikative dimension med ind i forskningsprocessen, og forskeren får mulighed for at diskutere det empiriske materiale i lyset af epistemologiske og ontologiske ståsteder. Makroniveauets dramaturgiske funktion ligger $i$, at det hjælper forskeren med at sammenflette den kunstneriske kontekst, som man er en del af (dramadidaktik), fænomenerne som der forskes på (de sociale medier) og forskningsdesign. I det følgende afsnit foretager jeg studiens sidste refleksive sideblik, og med udgangspunkt i teori om refleksiv forskning undersøges, hvad det er, der skiller forskeren som dramaturg fra andre forskningspositioner.

\section{Dramaturgi som refleksiv metodologi}

feg spejler min empiri $i$ min teori... I min metodik... I min epistemologi... I min ontologi. Et virvar af refleksive stemmer, som skal tolkes $i$ mit materiale; fagfolkenes, videnskabsteoriens, filosofiens, deltagernes, min egen. Et de-centreret (forsker) subjekt med FRAGMENTEREDE glimt af erkendelse. Ontologisk usikkerhed og selv-identisk kontinuitet, der skabes rum for DIVERGENS. Rum for FLERSTEMMIGHED. Rum for TRANSFORMATION. Feg står på skuldrene af teoretiske kcemper, men min udsigt er en anden end den de havde.

Ovenstående fortælling er en narrativ beskrivelse baseret på undertegnedes arbejde som kunstner-forsker med metodologi og det dramaturgiske som wide-range teori. Forkastelsen af forskningsarbejde som en lineær aktivitet, hvor elementer og hændelser optræder i en forudbestemt rækkefølge, ræsonnerer med Mats Alvesson og Kaj Sköldbergs beskrivelse af refleksiv forskning (2008, s. 537). Ifølge Alvesson og Sköldberg bærer refleksiv forskning med sig en idé om et konstant spejlingsforhold mellem empiri og metateoretiske refleksioner (Alvesson \& Sköldberg, 2008). De beskriver refleksiv forskning som at bevæge sig i en spejlsal mellem konvekse og konkave spejle. De argumenterer for, at kompleksitet og mangfoldighed skal ses som en intention og ikke en svaghed i refleksiv forskning. Et andet centralt element hos Alvesson og Sköldberg berører forskerens kontinuerlige vurdering af, hvordan empiri håndteres, og hvordan teoretiske referencerammer både tilbyder nye indsigter og skygger for andre på samme tid (Alvesson \& Sköldberg, 2008). Ved at reflektere over hvordan forskellige aspekter påvirker hinanden, åbnes der op for divergerende tolkninger.

Alvesson og Sköldbergs teori om refleksiv forskning ræssonerer med det dramaturgiske som et kommunikativt mødested. Både Pavis og Szatkowski argumenterer for, at forskeren anvender et bredt teoretisk rammeværk, som rummer divergerende tolkninger. Den kunstbaserede forsknings strategier kan gøre det udfordrende for forskeren at navigere $i$ et metodologisk krydsfelt, som i takt med flere og flere divergerende tolkninger bliver mere og mere komplekst. Her kan det dramaturgiske hjælpe forskeren med at formidle valg af form og indhold på en kritisk og transparent måde. Dramaturgi som refleksiv metodologi tilfører forskeren et bredt tolkningsrepertoire, hvor dramaturgiske komponenter som divergens, fragmentering, transformering og 


\section{K. N. Knudsen}

flerstemmighed er styrende for den refleksive forskningsproces. Komponenterne tilfører forskeren strategier, som kan implementeres i forskningsdesignets mikro- og makroniveau. Kunstner-forskeren behøver ikke nødvendigvis at anskue hele forskningsprocessen som et teaterlaboratorie. Men både kunstpraksis og forskningsfænomen bør relatere sig til sociale og relationelle kontekster, som undersøger, hvordan subjektet skaber mening i samfundets komplekse kommunikative strukturer. Det vil også inkludere steder, hvor der arbejdes med forskning og andre former for læringsog meningsskabende aktiviteter.

\section{At forske i et krydsfelt}

A hyper-complex society needs complex theories (Szatkowski, 2017).

Artiklen havde til hensigt at undersøge, hvordan dramaturgi som et teoretisk koncept kunne fungere som en metodologisk platform i relation til kunstbaseret forskning. Med henvisning til ovenstående citat, så kan det dramaturgiske danne et teoretisk rammeværk, hvormed vor tids komplekse kommunikative strukturer kan observeres og analyseres, også i en kunstbaseret forskningskontekst. Kunstbaserede forskningsprocesser kan beskrives som at navigere i krydsfelter, hvor kunstpraksis møder forskningsfænomener, hvor praksis møder teori, og hvor kunst møder videnskab. Det er en krævende, kreativ og udfordrende forskningsproces, som kan være vanskelig at give sig hen til. Med udgangspunkt i mine egne erfaringer med kunstbaseret forskning har jeg skrevet et forslag til dramaturgi som refleksiv metodologi. En metodologi, som åbner op for at rumme metodisk pluralisme og bevægelighed i relation til kunstner-forskerens epistemologiske og ontologiske positionering. Forskeren som dramaturg skal blandt andet kunne analysere meningsskabende processer på et mikroniveau, hvor mening ikke altid udtrykkes i diskursive former, men som kan konstrueres ved hjælp af metaforer fra forskerens egen kunstpraksis. Forskeren som dramaturg skal også kunne diskutere og kritisk reflektere over forskningen på et makroniveau, hvor divergerende tolkninger i relation til epistemologiske og ontologiske ståsteder indgår $\mathrm{i}$ et konstant spejlingsforhold mellem empiri og metateoretiske refleksioner. Jeg foreslår, at det at tænke som en dramaturg kan hjælpe kunstner-forskeren med at formidle valg af form og indhold på en refleksiv og transparent måde.

\section{Forfatteromtale}

Kristian Nødtvedt Knudsen har en doktorgrad i drama/teaterfagdidaktik fra NTNU Institut for lærerutdanning i Trondheim. I sit doktorgradsprojekt undersøger Kristian, hvordan det performative og digitale samfund kan stimulere til drama/teaterfaglig fornyelse. I sin forskning udforsker han, hvilke læringsmuligheder der opstår i krydsfeltet mellem sociale medier og drama som læringsform. Kristian har en bachelorgrad i Dramaturgi fra Aarhus Universitet og en mastergrad i Dramapædagogik fra Høgskolen i Bergen. Efter studietiden blev Kristian boende i Bergen og arbejdede som freelancer $\mathrm{i}$ forskellige sammenhænge, blandt andet som underviser på teaterskoler for børn og unge. Han har ligeledes erfaring fra det frie scenekunstmiljø som instruktør og improvisationsskuespiller. 


\section{Forskeren som dramaturg - dramaturgi som refleksiv metodologi}

\section{Litteraturliste}

Allern, T.H. (2003). Drama og erkjennelse. En undersøkelse av forholdet mellom dramaturgi og epistemologi $i$ drama og dramapedagogikk. (Diss.). Trondheim: NTNU, Institut for kunst- og medievitenskap.

Alvesson, M. \& Sköldberg, K. (2008). Tolkning och reflektion. Vetenskapsfilosofi och kvalitativ metod (2. Udgave). Lund: Studentlitteratur.

Barthes, R. (1977). Image Music Text. London: Fontana Press.

Dewey, J. (1934/1980). Art As Experience. New York: Perigee Books

Fels, L. (2015). Performative Inquiry: Releasing regret. I S. Schonman (Red.), InternationalYearbook of Research in Arts Education (s. 477-481). Münster, New York: Waxmann.

Gergen, K. J. \& Gergen, M. (2018). The Performative Movemenet in Social Science. I P. Leavy (Red.), Handbook of Arts-Based Research (s. 54-67). New York: The Guilford Press.

Giddens, A. (1991/2013). Modernity and Self-identity. Self and Society in the Late Modern Age. Cambridge: Polity Press.

Gladsø, S., Gjervan, E. K., Hovik, L. \& Skagen, A. (2015). Dramaturgi Forestillinger om teater (2. udg.). Oslo: Universitetsforlaget.

Gjærum, R. G. \& Rasmussen, B. (red.). (2012). Forestilling, framføring, forskning: Metodologi $i$ anvendt teaterforskning. Trondheim: Akademika forlag.

Haseman, B. (2006). A Manifesto for Performative Research. Media International Australia Incorporating Culture and Policy: quarterly journal of media research and resources, vol. 118, 98-106.

Heggstad, K. M. (2012). 7 veier til drama. Grunnbok $i$ dramapedagogikk for lerere $i$ barnehage og skole (3. udg.). Bergen: Fagbokforlaget.

Kershaw, B. (2006). Performance Practice as Research. I L. Elkjær (red.), Re.Searching: om praksisbaseret forskning $i$ scenekunst (s. 134-160). Malmö og København: NordScen.

Kjølner, T. \& Szatkowski, J. (1991). Dramaturgisk analyse for ikke naive regissøre I H. Reistad (red.), Regikunst (s. 122-132). Oslo: Tell forlag.

Knudsen, K.N. (2015). Sociale medier - en ny scene for dramapædagogen. Drama Nordisk Dramapedagogisk Tidsskrift, Nr. 3(2015), 46-50.

Knudsen, K. N. (2017a). Performative læringsrum på digitale scener-dramadidaktik og sociale medier. Fournal for Research in Arts and Sports Education, Vol 1, No 5. 1-16.

Knudsen, K.N. (2017b). \#iLive - konturer af en performativ dramadidaktik i en digital samtid. (Diss.). Trondheim: NTNU, Institutt for lærerutdanning.

Knudsen, K. N. (2018). Challenging fiction - exploring meaning-making processes in the crossover between social media and drama in education. International fournal of Arts $\mathcal{F}$ Education, Nr. 19(1), 1-24.

Nicholson, H. \& Kershaw, B. (2011). Research Methods in Theatre and Performance. Edinburgh: University Press.

Pavis, P. (2014). Dramaturgy and Postdramaturgy. I K. Pewny, J. Callens, J. Coppens (red.), Dramaturgies in the New Millennium. Tübingen: Narr Verlag.

Peirce, C.S. (1998). The Essential Peirce. Selected Philosophical writings. Volume 2 (193-1913). Peirce Edition Project (red.). Bloomington and Indianapolis: Indiana University Press.

Rancière, J. (2004). The Politics of Aesthetics. New York: Continuum.

Rancière, J. (2009). Aesthetics and its Discontents. Cambridge: Polity Press.

Rasmussen, B. (2012). Kunsten å forske med kunsten. Et blikk på kunnen ut fra praksis-teori-relasjonen. I R. Gürgens Gjærum \& B. Rasmussen (red.), Forestilling, framføring, forskning: Metodologi i anvendt teaterforskning (s. 23-49). Trondheim: Akademika forlag.

Rasmussen, B, (2013). Fra erfaring til refleksiv kunnskap. I A.L. Østern, G. S. Karlsen \& E. Angelo (red.), Kunstpedagogikk og kunnskapsutvikling (s. 261-272). Oslo: Universitetsforlaget.

Shusterman, R. (1992/2000). Pragmatist Aesthetics. Living Beauty, Rethinking Art. Oxford: Rowman \& Littlefield Publishers.

Smith, D. \& Dean, R.T. (2009). Practice-led research, research-led practice in the creative arts. Edinburgh: Edinburgh University Press.

Szatkowski, J. (1989). Dramaturgiske modeller - om dramaturgisk tekstanalyse. I E.E. Christoffersen, T. Kjølner \& J. Szatkowski, Dramaturgisk analyse. En antologi (s. 9-92). Århus: Universitetet i Aarhus, Institutt for dramaturgi.

Szatkowski, J. (2011). Person og rolle. Peripeti, (Scernummer), 111-135.

Szatkowski, J. (2017). Manifesto for a wide-range theory of dramaturgy. Peripeti, nr. 26, 10-28.

Sæbø, A. B. (2016). Drama som leringsform. Oslo: Universitetsforlaget. 


\section{K. N. Knudsen}

Ulvund, M. (2012). Ekkoteater : praksisledet forskning innenfor et performativt paradigme. I R. Gürgens Gjærum \& B. Rasmussen (red.), Forestilling, framføring, forskning: Metodologi $i$ anvendt teaterforskning (s. 51-75). Trondheim: Akademika forlag.

Østern, A.L. (red.) (2014). Dramaturgi i didaktisk kontekst. Bergen: Fagbokforlaget.

Østern, T.P. \& Letnes, M. A. (2017). Et temanummer som undersøker hva det innebærer å forske med kunsten. fournal for Research in Arts and Sports Education, Special Issue: «Å forske med kunsten», Vol. 1, no 5, 2017, 1-6. 